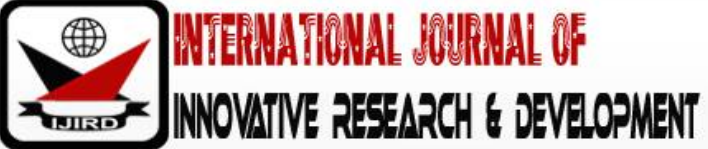

ISSN 2278 - 0211 (Online)

\section{Company Income Tax and Firm Performance in Nigeria: A Case of Selected Consumer Goods Sector (2010-2018)}

Olutoye Adedayo
Associate Professor, Department of Banking and Finance,
Afe Babalola University, Ado Ekiti, Nigeria
Olaoye Claudius Awoniyi
Ph.D. Student, Department of Banking and Finance,
Afe Babalola University, Ado Ekiti, Nigeria
Abiodun Thomas Ogundele
Lecturer, Department of Banking and Finance,
Afe Babalola University, Ado Ekiti, Nigeria
Ololade Tolulope Ibi-Oluwatoba
Ph.D. Student, Department of Banking and Finance,
Afe Babalola University, Ado Ekiti, Nigeria

\begin{abstract}
:
This study perceived company income tax as the economic responsibility of the firms to the government rather than seeing it as a cost that reduces the profitability and performance of firms. Majority of studies had focused on relationship between taxation and economic growth while there is depth of studies in regards to firm's performance. Hence, this study examined the effect of company income tax on firm's performance especially the consumer goods firms in Nigeria spanning 2010 to 2018. Performance was proxied by return on asset (ROA) while company income tax (CIT), valued added tax (VAT) and tertiary education tax (TET) were the explanatory variables. Cross sectional data were sourced in respect of these proxies from three (3) manufacturing firms who are specialized in consumer goods production while estimation was done using Random panel regression. The study found that company income tax and valued added tax have positive and significant effect on return on asset while tertiary education tax has insignificant negative effect on return on asset. Hence, the study concluded that company income tax significantly and positively impacted on firm performance of consumer goods firms in Nigeria. It is therefore recommended that, prompt payment of taxes by firms should be encouraged after adopting necessary incentives that might have been given by government, as this would increase the revenue of government and as well enable government to provide necessary infrastructure that would enhance the operations of the consumer goods firms in Nigeria.
\end{abstract}

Keywords: Company income tax, valued added tax, tertiary education tax, return on assets, firm performance, Nigeria

\section{Introduction}

Tax serves as a means of revenue generation to the government for the purpose of financing its administration and also to provide public goods or social infrastructure for the populace. In Nigeria, much attention has not been given to tax as a means of raising funds because of the much concern of government on proceeds from crude oil which generates much needed revenue for government. According to Nwoba, Nwonu and Agbaeze (2017) revenue generation from crude oil was said to account for about $80 \%$ while $20 \%$ was accounted for by non- oil revenue and this has continued to repeat itself year in year out. This was supported by Okeke, Mbonu and Amahalu, 2018). Although, the percentage increase or decrease fluctuates between oil and non-oil sector, however, oil sector generates more revenue to the government and this has remained the reason for the neglect and under development of other sectors in Nigeria.

Despite huge income from oil sector, it has become a thing of concern to government when crude oil price fluctuates downward, thereby affecting the expected revenue needed for the running of government. There have been many cases in the past when the proposed budget are affected due to dwindling oil prices; some of which are 2008-2009 which was the period of global economic financial crises when oil prices crashed from over 140 dollars per barrel to a low of 40 dollars per barrel in a matter of days. Also, in 2014 when oil price was $\$ 114,2015$ when it was dropped to $\$ 62.19$ in 2015, 2016 when it was further declined to $\$ 28$ per barrel (Eboh, 2020; Nwoba et al, 2017) etc. Of recent, the break of COVID 19 pandemic around the globe has also affected the price of crude oil due to low demand for crude oil globally and countries that relied on oil as a means of raising revenue for the purpose of financing her budget like Nigeria, are seriously affected (Eboh, 2020). For example, Nigeria budget for 2020 was prepared based on oil bench mark of $\$ 57$ per barrel, 
however, at this present time, this is not sustainable for the country as the price has dropped to $\$ 28$ per barrel. Hence the need to rebased or re-assessed the budget so as to ensure that it performs to the expectation.

To solve this problem, federal government through federal inland revenue service has realized the need to implement different tax policy reform with the purpose of diversifying the revenue portfolio of the country to safeguard against the volatility of crude oil prices and to promote fiscal sustainability and economic viability. In line with this, Nigerian government took a bold step on various tax law reforms so as to improve tax and increase tax yield. Some of these are valued added tax Amendment that changed the rate from 5\% to $7.5 \%$ in 2020. Also, the company income tax amendment, personal income tax act etc, all these aimed at encouraging tax compliance and to bring about an increment in tax yield.

Studies on the relationship between taxation and economic growth in Nigeria and other emerging economies are numerous and majority of the findings affirmed the existence of positive and significant impact of taxation on economic growth. Some of these studies are; Adefeso (2018) Okeke, Mbonu and Amahalu, 2018). This implies that, a good tax system can bring about a better economy most especially when such proceeds are efficiently utilized to impact the lives of the citizens. This was also supported by Odusola (2006) as he argued that for non-oil revenue to increase in value consistently, the various tiers of government are required to seek improvements in the treatment of the taxpayer, tax administrator, investment for the tax system and the way in which taxpayers' money is spent. However, the study found depth of studies on the relationship between company income tax and firms' financial performance in consumer goods sector. Hence, there is need to analyzed the relationship between the duo.

Although, there is an argument that government seek to achieve economic objectives of which in many cases need sustainable flow of revenue to achieve them, and in achieving this, it imposes taxes on individuals, goods and corporate. On the other hand, economic entities seek towards achieving corporate and financial performance and in achieving this, they ensure that tax is reduced, leverage is minimal and profit is maximized. Hence, this actually created a conflict of interest between the two. Although findings on the existing empirical studies varies, while some are in support of positive effects studies such as (Chude \& Chude, 2015; Ifrueze, John, Akmelu and Iyidiobi, 2018; Oladipo, Iyola, Fakile, Asaleye \& Eluyeli, 2019; Otwani et, 2017; Uwaoma \& George (2015). Others are in support of negative effect, these studies are Beigi, Rafat \& Tanah, 2013; Gatsi, Gadzo \& Kportorgbi 2013; Kurawa \& Saidu, 2015; Pitulice, Ștefănescu, Mînzu, Popa and Niculescu, 2015).

\section{Literature Review}

\subsection{Conceptual Literature}

Taxation has been conceptualized in many ways, however, most of the definitions tend to give the same meaning and explanation to what taxation means. From Omotosho (2001), it is defined as the compulsory charge imposed by a public authority on the income of individuals and companies as stipulated by government decrees, acts or laws irrespective of the exact amount of services rendered to the payer in return. This explains that, taxation is charged on both individuals and companies located and situated within a country and it is compulsorily imposed by government of such country.

According to Abata (2014) as cited by Oladipo (2015) taxation encompasses allocation of funds from the private sector to the host community for the creation of social goods which would improve economic and social goals. This emphasis that, the proceeds of taxation as received by government from private sector and individuals are also channeled back to the community in form of social amenities that can improves the welfare and standard of living of the people, which is one of the goals of the government.

Another view by IMF as cited by Beigi, Rafat and Panah (2013) is that, taxation is seen as compulsory, irrevocable and non-compensated payments which are required by the government for public purpose. This definition explained that, tax payment is compulsory and it is used majorly for the provision of public needs. In most of the times, these public needs can be social and economic, that is, health, education, road construction, transport system, rail system, air system, power and many other needs of the people, all these do not only improves the well-being of the citizens, but it also improves the social and economic infrastructure of the economy. This was supported by Oladipo (2015) as he emphasized that tax revenue by government is considered to be the utmost controlling charges accessible or reliable sources available to government in order to stabilize and promote its economic and social improvement

Sheriff and Agrawwal (2017) see it as a fee charged or levied by government on a product, income or activities. It is levied on individuals or goods or services. They emphasized the reason for this is to finance government expenditure and to redistribute wealth which translates to financing development of the country. The National Tax Policy (2012) conceptualized that taxation is basically the process of collecting taxes within a particular location. It is also seen as a pecuniary burden lay upon individuals or property to support government expenditure. This explains that imposition of tax should be within a particular jurisdiction and that it is necessary in order to support government expenses which comprises administration and economic expenses.

There are different forms or types of tax imposed on citizens (companies and individuals). According to Ayodele (2004) as cited by Sheriff and Agrawwal (2017) tax is charged based on the way it is classified, the first is incidence of tax, which is based on who is carrying the burden or who is to bear the final burden of tax. Under this, tax can be classified as direct and indirect tax. The direct tax is the tax on income or property whose burden cannot be shifted while the indirect tax is the type of tax which can be shifted, they are taxes on consumption or production of certain goods or services which can be easily be shifted to the final consumer. The second classification is according to bases, that is, on the object the tax is levied. Example of this are, personal income tax, company income tax, Petroleum Profit Tax (PPT), Capital Gains Tax 
(CGT), Value Added Tax (VAT), Excise Duty, and Custom Duty while the third is according to rates. This is based on progressive, proportional or regressive tax. The progressive tax is explained to mean the tax that increases as the income increases, the proportional is the tax where the same rate is applied and regressive tax is the tax that rate reduces as the income increases.

However, taxation as a source of revenue to government performed so many roles among which are; to generate revenue for government and management of the economy. Broadly, taxation roles in an economy ensure bridge between the poor and the rich by using tax to equate the rich and the poor. It can also be used as a means through which resources are well distributed and allocated where it is mostly needed. Apart from this, through efficient utilization of tax, it can bring about improvement in the country major infrastructure and it is also used to protect the infant local industries and discouraged consumption of goods that are inimical to health

\subsubsection{Firm Performance}

Performance of firms have been discussed by many studies. Hence, it can be described in terms of profitability of firms. This means that, when discussing on performance of firms, profitability of firm comes to mind, which is the ability of firms to earn good returns from its operation, most especially from sales and investment. Firms whose primary business is the production of goods, which can be either consume or used for further production would expect high turnover as well as having good returns from its sales, that is, when the sales proceed, less the expenses is of adequate value. In addition, performance of firms can also be described when firms enter into capital investment which gives better returns to the firms, especially, when the firm's capital investment generates positive present value, that is, when the initial capital of the investment is lesser to the discounted cashflow from the investment. The positive present value goes in the long way in adding value to the firms and as well increase the shareholder's returns.

From another angle, performance has been described as the ability of the firms to efficiently used its available financial resources to achieve competitive advantage (Hansen \& Mowen, 2005). This explained the fact that the resources of firms are very limited, therefore, it should be utilized in such a way that it achieved its goal, which would make the firm be of competitive advantage over its competitors in the sector. Otwani, Namusonge \& Nambuswa (2017) also described financial performance as a term used as a general measure of a firm's overall financial health over a given period of time, and can be used to compare similar firms across the same industry or to compare industries or sectors in aggregation. From the explanation, it can be seen that, financial performance health of firms. In addition, for firms in the same industries, the same measurement can be used to compare the strength of the firms so as to know which of the is performing exceptionally or efficiently.

There are many performance measures which can be used by firms to actually know the extent of their performance and as well helped the firms make important and decisive decisions in respect to growth of the firm. These measurements are subdivided into accounting-based measurements and market-based measurements (Poddi \& Vergalli, 2009 as cited by Duke \& Kankpang, 2013; Uwalomwa, Obarakpo, Olubukola, Ozordi, Osariemen, Gbenedio \& Oluwagbemi, 2018). For accounting-based measurements, return on assets, return on equity, leverage, return on capital employed, net profit margin, asset turnover, profit after tax and many others can be used. The market-based measurement gives information about the firm's market value and the entitlement of shareholders. This measurement helps the company shareholders and intending investors to screen and makes decisions in respect to the firm. It actually explained the extrinsic value of the firms. Some of these are Earnings per share, dividend per share, dividend yield, price earnings ratio, Tobin's Q etc (Nwokeji, Osisioma \&Benjamin, 2019, Otwani et al, 2017).

\subsection{Theoretical Framework}

The study adopts as its theoretical underpinning ability-to-pay approach theory. This theory is based on ability of taxpayers to pay thus there is no quid pro quo. The underlying principle of this theory says that, taxes paid are seen as a sacrifice by taxpayers, which raise the issues of what the sacrifice of each taxpayer should be and how it should be measured. As a result, this theory is based on the following principle, equal sacrifice which total loss of utility as a result of taxation should be equal for all taxpayers so that those who can afford to pay higher taxes are made to pay higher than those who cannot afford. The second is equal proportional sacrifice, which says that the proportional loss of utility as a result of taxation should be equal for all taxpayers such that the payment of taxation should not deprive anybody of what he or she would have previously sacrificed. The third is on equal marginal sacrifice, this is measured by the derivative of the utility function as a result of taxation should be equivalent for all taxpayers.

\subsection{Empirical Review}

In Ugandan, Myende (2013) analyzed the effects of tax incentives on the performance of Ugandan manufacturing firms using cross sectional data running from 2000 to 2002 by carrying out a survey on 392 firms across four sector such as agriculture, construction, manufacturing and tourism. Data on gross sales, cost of raw materials, capital stock, labour force employed, wages and salaries, cost of production, sector of the firm, ownership of the firm, ages of firms, and education levels of manager were sourced and estimated using panel regression. The study showed that firms with tax incentives perform better in terms of gross sales and value added than their counterparts. The education level of managers of firms, firm-size, and age of the firm have positive impact on firm performance.

In Pakistan, Beigi, Rafat and Panah (2013) evaluated the effect of tax on profitability indices in listed companies in Tehran stock exchange covering a period from 2004 to 2010. Three models were estimated of which return on assets, return on asset by adjusting the financing cost and return on equity while, type of industry, size, age, ratio of capital to asset, ratio of debt to asset and tax were explanatory variables used. The study estimated using panel regression of data 
sourced in respect of these proxies on 28 companies. The study revealed that, debts to asset ratio and the type of the industry showed a negative effect on profitability and at the same time, capital ratio to asset and the size of the company indicated positive significant effects on profitability index.

Likewise, in Ghana, Gatsi, Gadzo and Kportorgbi (2013) assessed the effect of corporate income tax on financial performance of listed manufacturing firms covering a period 2005 to 2012. Return on assets was the proxy for dependent variable while company income tax, age, firm size, liquidity and growth were explanatory variables. Data for the study were sourced from the financial statement of the 10 listed firms and estimated using panel regression. The study showed that, there is a significant negative relation between corporate income tax and financial performance. On the other hand, firms' size, age of the firm and growth of the firm show a significant positive relationship with financial performance.

In Nigeria, Ejiofor, Adigwe and Nwaolisa (2015) examined the impact of fiscal policy on manufacturing companies' performance using an annual time series covering period from 2008 to 2012. Company tax was regressed on the company's turnover and data sourced were from three manufacturing companies. Data sourced were analyzed using ANOVA. They found that, there is a significant effect of fiscal policy on the performance of Nigerian manufacturing companies.

Also, Chude and Chude (2015) assessed the impact of company income taxation on the profitability of companies in Nigeria spanning 2000 to 2012. Earnings per share was used to measure profitability while company income tax was used as independent variable to represent company tax. Data were sourced from companies' annual financial statement and estimated regression, the study revealed that the level of company tax has significant and positive effect on the profitability, that company income tax (CIT) has significant effect on profitability.

Pitulice, Ștefănescu, Mînzu, Popa and Niculescu (2015) examined corporate tax impact on financial performance of companies listed on Bucharest stock exchange for the period 2012 to 2014. The study regressed effective tax rate, form size, asset structure, dent ratio and leverage which are explanatory variables with net profit which is the dependent variable. Cross sectional data were sourced from the financial statement of the 20 sampled firms listed on the Bucharest stock exchange and estimated using panel regression. The study showed that, the effective tax rate has negative and significance effect on the performance of firms.

However, Uwaoma and George (2015) analyzed the relationship between valued added tax and financial performance of agricultural quoted business in Nigeria using quantitative and qualitative data. Quantitative data were sourced from 42 respondents in the agricultural sector which include the General Managers, Chief Accountants, Finance Managers, Chief Internal Auditors, External Auditors, and Tax Administrators of the selected companies, On the other hand, return on investment and return on equity were used as dependent variable while valued added tax was the independent variable and analyzed using Anova. The study showed that valued added tax has insignificant positive on return on investment and insignificant negative on return on equity.

Otwani, Namusonge and Nambuswa (2017) analyzed the effect of corporate income tax on financial performance of companies listed on Nairobi Stock exchange for 2015. Return on investment and net profit of firms were used to represent dependent variable while corporate income tax, investment size, debt ratio and liquidity represented explanatory variables. Data were sourced from 59 companies from 10 different sectors using survey by administration of questionnaires. The study found that, that there is a positive relationship between corporate income tax and financial performance of listed companies on the NSE in Kenya

At the same time, Adefeso (2018) looked the effects of government tax policy on performance of the manufacturing firms in Nigeria spanning 1990 to 2012. The model specification had output of the firms the proxy for performance and corporate tax, age, risk and free cash flow as explanatory variables. data were sourced cross sectionally from the selected firms and estimated using Generalized method of moment. The study found positive relationship between corporate tax policy and the output performance of quoted manufacturing firms in Nigeria.

Same in Nigeria, Kurawa and Saidu (2018) investigated the relationship between corporate tax and performance of the listed Nigerian consumer goods between 2006 to 2016. The study employed return on assets as the dependent variable, to proxy performance and as well represented independent variable by effective tax rate, firm size, age and size. Cross sectional data were sourced from the comprehensive income and financial position of 10 companies and estimated using panel repression. They found an insignificant negative relationship between corporate tax and return on assets while age and risk exhibited insignificant positive relationship with return on asset. Size on the other hand showed positive and significant relationship with performance confirming prior expectations.

Same in Nigeria, Ifurueze, John-Akmelu and Iyidiobi (2018) examined the effect of corporate tax aggressiveness on firm growth between 2007 and 2016. Firm growth proxied by profit after tax were regressed on leverage and effective tax rate by sourcing data from the seven consumer goods firms and estimated using regression technique. The study found that effective tax impact on firm growth positively and significantly while the impact of leverage was negative and insignificant.

Okeke, Mbonu, and Amahalu (2018) investigated the effect of tax revenue on economic development in Nigeria using annual time series over a period 1994 to 2016. The study regressed petroleum profit tax, company income tax, valued added tax, personal income tax export duty, import duties against school enrollment, life expectancy and per capita. Secondary data were sourced National Bureau of Statistics and estimated using Johansen co-integration and error correction mechanism. The study found tax revenue has a statistically significant relationship with primary school enrolment, life expectancy and per capita income, in Nigeria

In ASEAN, Yoke and Chan (2018) examined the impact of valued added tax and export performance on manufacturing performance over a period 1985 to 2014. Manufacturing valued added and export intensity to proxy dependent variable while ratio of vat to GDP, wage rate, education, foreign direct investment, employment, real GDP per 
capita and ICT. Secondary Data were sourced and estimated suing regression. It was found that valued added tax has negative effect on manufacturing performance while VAT is positively and significantly associated with export intensity.

More so, Oladipo, Iyoha, Fakile, Asaleye and Eluyela (2019) questioned by asking if government taxes actually have any implication on manufacturing sector output in Nigeria using a quarterly data running from 2000 to 2016. Output of the manufacturing sector was the dependent variable while company income tax, valued added tax and manufacturing capacity utilization were the explanatory variables. By sourcing secondary data and estimating using auto regressive distributed lag, the study revealed a significant positive relationship between corporate taxes and manufacturing output in the long run while VAT has significant negative on manufacturing output. In the short run, findings showed a reversal where VAT has positive and significant effect on manufacturing output and corporate income tax has negative effect on manufacturing output.

Most importantly, Fagbemi, Olaniyi and Ogundipe (2019) examined corporate tax planning and financial performance of systemically banks in Nigeria. Performance was proxied by return on equity while effective tax rate, investment of banks in non-current assets, debt ratio, lease options, size, managerial efficiency and capital adequacy as explanatory variables. Cross sectional data were sourced from the annual financial statement of the eight (8) sampled banks and estimated using correlation and panel regression. The study found that, the effective tax rate has significant negative impact on financial performance. On the other hand, thin capitalization has a positive significant impact on the financial performance while capital intensity and the lease option have demonstrated an insignificant impact on the financial performance. The study therefore summarized its findings that corporate tax planning affects financial performance depending on the adopted tax planning strategies

\section{Methodology}

The methodology covers, research design, population of study, data collection methods used and data analysis technique applied in the study. The study employed ex-post facto research design, of which, secondary data were sourced from three manufacturing companies' annual comprehensive income and financial position statement of various editions covering the period of 2010-2018. These three manufacturing companies are Cadbury Nigeria Plc, Nestles Nigeria Plc, and Unilever Nigeria Plc. In this study, return on asset was the proxy for firm performance while company tax, valued added tax and tertiary education tax were used as proxies to cover different tax of the firms.

\subsection{Model Specification}

The model specification for this is adopted from Ifurueze, John-Akmelu and Iyidiobi (2018) which specified that PAT $=\mathrm{f}(\mathrm{EIT}, \mathrm{LEV})$

The above tax explained that profit after tax is a function of effective tax rate and leverage. This model is adapted with modification by replacing EPS by ROA and by adding other different taxes paid by consumer goods companies such as company income tax, education tax and valued added. As a result, the new model for the study is specified as

ROA $=f($ CTAX, ETAX, VAT)

In an explicit or linearized form, the model is stated as;

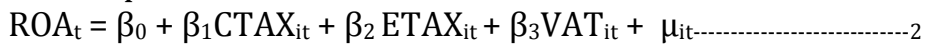

Where,

ßo

ROA

CTAX

ETAX

VTAX

$\mu$

$\beta_{1-------} \beta_{3}$

\section{$=\quad$ Constant Term}

$=\quad$ Return on assets

$=\quad$ Company income tax

$=\quad$ Tertiary Education Tax

$=\quad$ Valued Added Tax

$=\quad$ stochastic error terms

$=\quad$ Parameters to be estimated

\subsection{Sources of Data and Estimation Technique}

Cross sectional data were sourced from annual financial statement of the selected manufacturing firm in the consumer goods sector such as Cadbury Nigeria Plc, Nestles Nigeria Plc, and Unilever Nigeria Plc and it covered a period from 2010 to 2018. The study employed, descriptive statistics, correlation matrix and Random panel regression as the estimation techniques

\section{Analysis and Interpretation of Result}

\subsection{Descriptive Statistics}

Descriptive statistics was used to examined the characteristics of variables of interest employed in this study and the result is presented in Table 1 . The mean and the median of the variables were compared and it gives information about the skewness of the variables. The mean of ROA 13.9910 is greater than its median of 11.936 , this means that ROA is skewed to right by 0.8933 . The mean of CTAX 7793 is greater than its median of 5585 which means that the CTAX is skewed to the right, that is positively skewed by 0.5928 . The average mean of ETAX 630.46 is greater than its median of 335.00 , this means that, ETAX is positively skewed by 0.368 . It was also found that the mean of VTAX 3920.30 is greater than its median of 1190.50 which indicates that the VTAX is positively skewed by 0.9066 . It was also showed that all the variables examined are positively skewed; this indicates that the distribution has long right tail. The standard deviation, measures the degree of dispersion from the mean value, hence, from the result, it was CTAX that has the highest value of 
7250, followed by VTAX of 4270 while the least volatile variable is ROA of 9.6882 . The kurtosis statistics measure the difference of the skewness and kurtosis of the series with those of the normal distribution and it was revealed that most of the variables have kurtosis value that is greater than 3.0, and approximately equal to 3 which indicates that, variables in the series are peaked. That is, the distribution is leptokurtic relative to normal distribution. Jargue Bera revealed that, most of the variables are normally distributed as they have value above $5 \%$ level of significant. Observations is 27

\begin{tabular}{|c|c|c|c|c|}
\hline & ROA & CTAX & ETAX & VAT \\
\hline Mean & 13.99110 & 7793.150 & 630.4615 & 3920.308 \\
\hline Median & 11.93651 & 5585.000 & 335.0000 & 1190.500 \\
\hline Maximum & 43.63751 & 24086.00 & 1548.000 & 13048.00 \\
\hline Minimum & -1.04255 & 45.00000 & 0.000000 & 0.000000 \\
\hline Std. Dev. & 9.688269 & 7250.064 & 586.3323 & 4270.074 \\
\hline Skewness & 0.893385 & 0.592842 & 0.368896 & 0.906682 \\
\hline Kurtosis & 4.312686 & 2.086764 & 1.347534 & 2.394212 \\
\hline Jarque-Bera & 5.530156 & 2.519827 & 3.547894 & 3.959871 \\
\hline Probability & 0.062971 & 0.283679 & 0.169662 & 0.138078 \\
\hline Sum & 377.7598 & 210415.1 & 16392.00 & 101928.0 \\
\hline Sum Sq. Dev. & 2440.426 & $1.37 \mathrm{E}+09$ & 8594638. & $4.56 \mathrm{E}+08$ \\
\hline Observations & 27 & 27 & 26 & 26 \\
\hline
\end{tabular}

Table 1: Summary of Descriptive Statistics

Source: Authors Computation Using Eviews, 9

The results of the correlation matrix, showing the correlation between the variables is presented in Table 2 . Result revealed that, there is moderate positive correlation between the variables employed. It was found that, performance measurement which is ROA has positive correlation with all the explanatory variables such as ETAX, CTAX and VTAX. It was also found that, positive correlation exists between the explanatory variables. Hence, it expected that the explanatory variables should have a statistically influence on return on assets. However, this result can be said to be normal as the variables are relatively correlated which is an indication that the variables have no multicollinearity problem.

\begin{tabular}{|c|c|c|c|c|}
\hline & ROA & ETAX & VAT & CIT \\
\hline ROA & 1 & & & \\
\hline ETAX & 0.132102 & 1 & & \\
\hline VAT & 0.095335 & 0.689507 & 1 & \\
\hline CTAX & 0.305397 & 0.9165 & 0.595777 & 1 \\
\hline
\end{tabular}

Table 2: Summary of Correlation Matrix

Source: Authors Computation using Eviews, 9

Before the main estimation, it is necessary to carry out Durbin Hausman test so as to know which options would be better use for the study between fixed and random effects. The result of the Hausman test is presented in Table 3 . It was found that, the p-value test for ROA is 0.1681 which is greater than $5 \%$, hence, the null hypothesis can't be rejected. The null hypothesis says that, Random effect is appropriate; hence, random effect was used as the estimation method

\begin{tabular}{|c|c|c|c|}
\hline Test Summary & Chi-Sq. Statistic & Chi-Sq. d.f. & Prob. \\
\hline Period random & 5.051357 & 3 & 0.1681 \\
\hline \multicolumn{4}{|c|}{ Table 3: Summary of Hausman Test } \\
Source: Authors Computation using Eviews, 9
\end{tabular}

The result of the random effect of panel analysis is presented in Table 4. It was found that, company tax has positive impact on the return on assets while firm size has a negative effect on return on assets. CTAX of 0.0023 and VAT of 0.0002 positively impacted on return on assets while ETAX of -0.0022 has negative effects on return on assets. The implication is that, all things being equal, $1 \%$ increase in CTAX and VAT would bring about $0.2 \%$ and $0.02 \%$ increase in the return on assets while 1\% increase in ETAX would bring about $0.2 \%$ decrease on return on assets. Checking their level of significant at 5\%, findings revealed that, CTAX and ETAX are statistically significant on return on assets.

The coefficient of determination $\left(\mathrm{R}^{2}\right)$ of 0.5912 , explained that, about $59.12 \%$ variation in ROA was explained by the joint effect of explanatory variables employed while the remaining of 40.88 are explained by the variables that can enhance the performance but not included in the model. The adjusted $\mathrm{R}^{2}$ of $50.82 \%$ also explained the variation in dependent variable based on the number of variables in the model. The F-statistics explained the overall significant of the model and it was found that, F-statistics of positive 4.7136 and its corresponding p-value of 0.0109 showed that, the model 
is statistically insignificant. Durbin Watson result of 1.5719 in its approximation form is close to 2 which imply that, the variables employed in this study are not having problem of serial correlation. This is further authenticated by the normality test in the appendix with Jargue beta value of 0.34 . On the basis of this, the study submitted that, variables selected have significant impact on firm profitability in Nigeria

\begin{tabular}{|c|c|c|c|c|}
\hline Variable & Coefficient & Std. Error & t-Statistic & Prob. \\
\hline CTAX & 0.002302 & 0.000631 & 3.645314 & 0.0014 \\
\hline ETAX & -0.02287 & 0.007889 & -2.89907 & 0.0083 \\
\hline VAT & 0.000264 & 0.00054 & 0.489612 & 0.6293 \\
\hline C & 10.95775 & 2.486796 & 4.406372 & 0.0002 \\
\hline R-squared & 0.591272 & \multicolumn{2}{|c|}{ Mean dependent var } & 14.07013 \\
\hline $\begin{array}{c}\text { Adjusted R- } \\
\text { squared }\end{array}$ & 0.08263 & \multicolumn{2}{|c|}{ S.D. dependent var } & 9.871257 \\
\hline S.E. of regression & 8.209995 & \multicolumn{2}{|}{ Durbin-Watson stat } & 1482.888 \\
\hline F-statistic & 4.713638 & & \\
\hline Prob(F-statistic) & 0.010923 & & \\
\hline
\end{tabular}

Table 4: Summary of Random Panel Regression

Dependent Variable: ROA

Source: Authors Computation using Eviews, 9

\subsection{Discussion of Findings}

This study empirically examined the effects of taxation on performance of corporate firms in Nigeria covering a period 2010 to 2018. The study employed cross sectional data from the selected corporate firm such as Nestles Nig PLC, Cadbury Nigeria Plc and Nigeria Breweries Plc. Return on assets was used as measure for performance while company tax, tertiary education tax and valued added tax paid were used as proxies for independent variable. The study employed descriptive statistics, correlation matrix, Hausman test and Random panel regression as estimation techniques. Findings showed that, there is significant and positive impact of company tax and valued added tax on return on assets. Further findings showed that both company tax and valued added tax significantly impacted on ROA. The study therefore submitted that; corporate tax significantly impacted on return on assets in Nigeria. In line with findings of the existing studies, this study supported Otwani et, 2017, Adefeso, 2018, Ifrueze et al, 2018, Oladipo et al, 2018 and Uwaowa and George 2015 as they all supported that company tax positive and significant impact on firm's performance.

\section{Conclusion and Recommendations}

Having critically examined the effect of company tax on firms performance of the selected consumer goods in Nigeria, the study concluded that, company income tax is not just an outflow from company profit but it shows how responsible an organizations is to its immediate environment and also shows how committed a firm is in fulfilling its civic responsibility. Hence, this study concluded that there is positive significant effect of company tax on firm performance in Nigeria. The study recommended the following, first, the status quo of both company income tax and valued added tax should be sustained as this would enhance the performance of firms. Secondary, prompt payment of taxes by firms should be encouraged after adopting the necessary incentives that might have given by government as this would increase the revenue of government and it would enable government to provide necessary infrastructure that would enhance the operations of the consumer goods firms in Nigeria.

\section{References}

i. Adefeso, H.A. (2018). Government tax policy and performance of listed manufacturing firms in Nigeria: Evidence from Dynamic Panel Data Model. Zagreb International Review of Economics \& Business, 21(1), 1-15

ii. Beigi, R., Rafat, B., \& Panah, H.M. (2013). The analysis of the effect of tax on profitability indices in listed companies of Tehran Stock Exchange. European Online Journal of Natural and Social Sciences, 2(3), 86-98

iii. Chude, D.I., \& Chude, N.P. (2015). Impact of company income taxation on the profitability of companies in Nigeria. A Study of Nigeria Breweries. European Journal of Accounting, Auditing and Finance Research, 3(8), 1-11

iv. Duke, J.\& Kankpang, K. (2013). Implications of corporate social responsibility for the performance of Nigerian Firms. Advances in Management \& Applied Economics, 3(5), 73- 87

v. Eboh, M. (2017). Coronavirus: How drop in oil price affects Nigeria economy. Retrieved 06042020 from https://www.vanguardngr.com/2020/03/coronavirus-how-drop-in-oil- price-affects-Nigeria's-economy/

vi. Ejiofor, R.A., Adigwe, P.K., \& Nwaolisa, E.F. (2015). Tax as a fiscal policy and manufacturing company's performance as an engine for economic growth in Nigeria. European Journal of Business, Economics and Accountancy, 3(3), 1-12

vii. Emeka-Nwokeji, N.A., \& Osisioma, E., (2019). Sustainability disclosures and market value of firms in emerging economy: Evidence from Nigeria, European Journal of Accounting, Auditing and Finance Research, 7(3), 1-19

viii. Faggemi, T.O., Olaniyi, T.A., Ogundipe, A.A. (2019). The corporate tax planning and financial performance of systemically important banks in Nigeria. Ekonomski horizonti, 21(1), 15-28. 
ix. Gatsi, J.G., Gadzo, S.G., \& Kportorgbi, H.K. (2013). The effect of corporate income tax on financial performance of listed manufacturing firms in Ghana. Research Journal of Finance and Accounting, 4(15), 118-124

x. Ifurueze, M.S., John-Akmelu, R., \& Iyidiobi, F.C. (2018). Effect of corporate tax aggressiveness on firm growth in Nigeria: An Empirical Analysis. International Journal of Trend in Scientific Research and Development, 2(6), 16281639

xi. Kurawa J.M., \& Saidu, H. (2018). Corporate tax and financial performance of listed Nigerian consumer goods. Journal of Accounting and Financial Management, 4(4), 30-42

xii. Myende, S. (2013). The effects of tax incentives on firm performance: Evidence from Uganda. Journal of Politics and Law, 6(4), 95-107.

xiii. Nwoba, M. O. E., Nwonu, C. O., \& Agbaeze, E.K. (2017). Impact of fallen oil prices on the Nigeria economy. Journal of Poverty, Investment and Development, 33, 76-82

xiv. Odusola, A. (2006). Tax policy reforms in Nigeria. Research Paper No. 2006/03

xv. Okeke, M.N., Mbonu, C.M., \& Amahalu, N.M. (2018). Effect of tax revenue on economic development in Nigeria. International Journal of Research in Business, Economics and Management,2(4), 25-57

xvi. Oladipo, O.O., Iyoha, O.F., Fakile, A.S., Asaleye, A.J., \& Eluyela, D.F. (2019). Do government taxes have implications on manufacturing sector output? Evidence from Nigeria. Journal of Management Information and Decision Sciences, 22(3), 181-190

xvii. Otwani, M.N., Namusonge, G.S., \& Nambuswa, E.M. (2017). Effect of corporate income tax on financial performance of companies listed on the Nairobi securities exchange in Kenya. International Journal of Social Sciences and Information Technology, 3(8), 2467-2477.

xviii. Pitulice, I.C., Ștefănescu, A., Mînzu, V.G., Popa, A.F., \& Niculescu, A.M. (2015). Research of corporate tax impact on financial performance. Case of Companies Listed on Bucharest Stock Exchange. Management and Economics Review, 1(2), 204-216

xix. Poddi, L., \& Vergalli, S. (2009). Does corporate social responsibility affect the performance of firms? Institutions and Markets Series, Fondazione Eni Enrico Mattei Working Paper 52.

xx. Sheriff, A., \& Agrawwal, P.K. (2017). An assessment of the contribution of tax on Nigeria's economic development and its effects on companies' performance in Nigeria. International Journal of Scientific and Research Publications, 7(7), 476-484

xxi. Uwalomwa, U., Obarakpo, T., Olubukola, R.U., Ozordi, E., Osariemen, A., Gbenedio, A.E., \& Oluwagbemi, S.T (2018). Sustainability reporting and firm performance: a bi-directional approach. Academy of Strategic Management Journal, 17(3), 1-17.

xxii. Uwaoma, I., \& George, T.P. (2015). Value added tax and the financial performance of quoted Agribusinesses in Nigeria. International Journal of Business and Economic Development, 3(1), 78-86

xxiii. Yoke, L.M., \& Chan, S.G. (2018). The impact of value added tax on manufacturing performance in ASEAN. International Journal of Business, Economics and Law, 17(1), 7-15. 